\title{
ORIGIN, DEVELOPMENT AND BREEDING OF ARCHAEOPHYTES
}

\author{
Károly Ecseri ${ }^{1^{*}}$, Péter Honfi ${ }^{2}$ \\ ${ }^{1}$ Department of Horticulture, Faculty of Horticulture and Rural Development, John von Neumann University, \\ Hungary \\ ${ }^{2}$ Department of Floriculture and Dendrology, Institute of Sustainable Horticulture, Faculty of Horticultural \\ Science, Szent István University \\ https://doi.org/10.47833/2020.2.AGR.025
}

\section{Keywords: \\ speirochoric weeds \\ random selection \\ domestication \\ secondary cultivated plants \\ crop mimicry}

\section{Article history:}

Received 20 Apr 2020

Revised 10 May 2020

Accepted 20 May 2020

\begin{abstract}
The segetal plant species that were present in the flora of the European area before the discovery of America are called archeophytes. We usually do not have accurate data on their place of origin and the method of spread, but their migration is attached to human activity in all cases [30]. Most botanists classify these species as native plants rather than calling adventive [35]. Their number is generally small, with 186 taxa in the Hungarian preliminary list, which we can surely say are archaeophytes. $88 \%$ of them are annual species, which originally found in field cereals [33].
\end{abstract}

\section{Origin, anthropogenic dispersal}

Archeophytes did not exist before the evolution of human beings. This statement supported by the example of Cyanus segetum, which completely disappeared during the ice age, then appeared again at the beginning of arable crop production [29]. Papaver rhoeas was also formed with the appearance of man [19].

All archaeophytes taxa originally lived in the pioneer vegetation of another geographical area [4]. The process of nature transformation can help these "oldcomer" species [2], and leave their original habitat and integrate into the lifestyle of the nomad shepherding-cereal farming people. These plants similar to the crops not only in their seed parameters and some phenophases, but also lost many of their early characteristics [22]. Competition is less important in the case of species living in agricultural areas. The key of their success is rapid nutrient uptake and utilization [4].

It is generally true that they are only able to germinate under "optimal conditions". They produce few but larger seeds, usually germinate in autumn or early spring ( $T_{2}$ life form) [15].

\section{Random selection and domestication}

Element of the domestication process: seed mimicry ('speirochoric weeds'), uniform size and short vegetation [16]. Secondary cultivated plants (cultivated species evolved from weeds) [24] include, for example the wild from of peas (Pisum sativum subsp. arvense) [17] and the randomly selected chickling pea (Lathyrus sativus) which was the weed of the lentil [9]. Camelina alyssum [21] which perfectly adapted to lentil [31] and Lolium remotum also come from the weed flora of lentil [28].

The perfectly adapted [14] and nowadays protected corncockle (Agrostemma githago) [25] which seeds can be eaten after roasting [7], has also been used like arable crop in Russia [13]. In the case of low cover, the compounds of corncockle help the root development of cereal and increase

\footnotetext{
* Corresponding author. Tel.: +36 76517 655;

E-mail address: ecseri.karoly@kvk.uni-neumann.hu
} 
the number of grain yields [10] [26], so this archaeophyte is used as a bioregulator [11]. Taxonomically, it is very far from winter wheat belonging to Poaceae family, so there is no risk of genetic crossing [13].

An inverse process can be observed in the case of Bromus secalinus, which has already been cultivated in the Neolithic. Then displaced by the more productive cereals, but was not extirpate for centuries when it appeared among the rye because of their "crop mimicry" [12].

\section{Deliberate breeding - varieties of archaeophytes}

Hereinafter the major archaeophyte species and varieties were listed that are currently found in European commercial traffic [1][5][6][8][18][23][27][34][36][37]. The list is far from being complete, focusing mainly on ornamental annuals or some medically significant [3] species.

Adonis aestivalis,

Agrostemma githago (True Wild Form), 'Milas','Milas Purple Queen', 'Milas Snow Queen', 'Ocean Pearl',

Anagallis arvensis,

Anthemis arvensis,

Anthriscus cerefolium 'Fijne Krul'

Arctium lappa,

Bupleurum rotundifolium 'Griffithii', 'Garibaldi',

Centaurea cyanus 'Blue Boy', 'Blue Diadem', 'Black Boy', 'Red Boy', 'Snow Man', and color mixtures: 'Tall Double Mixed Colours', 'Burgundy Beauties Mix', 'Classic Romantic', 'Tall Double Mixed', 'Frosty Mixed', 'Midget Mixture','Polka Pot',

Consolida regalis 'Blue Cloud', 'Snowcloud', color mixture: 'Cloudy Skies',

Hibiscus trionum,

Isatis tinctoria,

Lathyrus sativus var. azureus

Marrubium vulgare,

Nepeta cataria,

Onopordum acanthium,

Orlaya grandiflora 'Snowballs',

Papaver dubium,

Papaver rhoeas 'American Legion', 'Red Corn', 'Birdal Silk', and color mixtures: 'Mother of Pearl', 'Shirley Single Mixed', 'Double Mixed', 'Angels Choir Mixed',

Saponaria officinalis,

Smyrnium perfoliatum.

\section{Summary}

The breeding of plants is the same age as humanity. The "breeding" of archaeophytes started at the beginning of the agriculture in the Neolithic. Their golden age certainly was in the Middle Ages. Arable crop production played a significant role at the same time, however the level of cultivation was not state of the art. In addition, the grower social class (serfdom) was not interested in the development of the cultivation method. In many cases, minimal seed selection has not been carried out, thereby cereal varieties have become stable or degraded over the centuries. At the same time, this low level of cultivation favored archaeophytes [20]. The other important center of this plants is found in the botanical gardens at this time. Only the native could be presented in these collections until the $16^{\text {th }}$ century, together with the archaeophytes [32].

Then in the New Age everything changed. Not only neophytes from the New World caused serious competition, but also the significant amount of fertilizer and herbicide application associated with the modernization of industrial agriculture. As a result, the habitat and number of "oldcomers" has decreased, but the degradation process can be observed not only in quantitative changes. Unnecessary use of chemicals has also severely damaged the genetic diversity of these plants. Many taxa both in Europe and in Hungary have become endangered moreover red-listed species in recent decades [25]. 
That is why it is important to use these plants in breeding, in addition to in situ protection. In this way, gene erosion can be reduced and perhaps attract the attention of the general public with the new ornamental varieties. The application of archaeophytes can bring back the atmosphere of wildflower fields, which were still natural in the age of our grandparents and great-grandparents, to the 21 th century gardens.

\section{Acknowledgment}

Thank you for the support of the research carried out in the framework of the EFOP-3.6.2-162017-00012 „Developing a functional, healthy and safe food product chain model from field to table in a thematic research network". The project is funded by the Hungarian State and the European Union, co-financed by the European Social Fund, and is part of the Széchenyi 2020 program.

\section{References}

[1] 123Seed (2004): www.123seed.com [16-04-2020]

[2] Balogh L. (2003): Az adventív-terminológia s. I. négynyelvű segédszótára, egyben javaslat egyes szakszavak magyar megfelelőinek használatára. [A quadrilingual auxiliary-dictionary of adventive-terminology s. I., and proposals for the use of certain terms in Hungarian]. Botanikai Közlemények. 90(1-2). p. 65-93.

[3] Bernáth J. (szerk.) (2000): Gyógy- és aromanövények. [Medicinal and aromatic plants]. Mezőgazda Kiadó. Budapest. p. 411-413, 434-436.

[4] Borhidi A. (2007): Magyarország növénytársulásai. [Plant associations of Hungary]. Akadémiai Kiadó. Budapest. p. 282-330.

[5] Burpee, W. A. (2014): www.burpee.com [16-04-2020]

[6] Chiltern Seeds (2014): www.chilternseeds.co.uk [16-04-2020]

[7] Degen Á. (1916): Konkolymérgezés. [Corncrockle poisoning]. Kísérletügyi közlemények. 19(1). p. 11-22.

[8] Dobies: www.dobies.co.uk [16-04-2020]

[9] Erskine, W., Smartt, J., Muehlbauer, F. (1994): Mimicry of lentil and the domestication of common vetch and grass pea. Economic Botany. 48(3). p. 326-332.

[10] Gajic, D. (1973): Increase of the free thyptothan content in wheat germ under the influence of Agrostemma githago. Fragmenta Herbologica Jugoslavica. 36. p. 1-10.

[11] Gajic, G. R. (2006): http://www.agrostemin.co.rs/opstipodacieng.php [16-04-2020]

[12] Gyulai F. (2001): Archaeobotanika. A kultúrnövények története a Kárpát-medencében a régészeti-növénytani vizsgálatok alapján. [Archaeobotany. History of cultivated plants in the Carpathian Basin based on archeological and botanical studies]. Jószöveg Kiadó. Budapest. p. 33, 67-200.

[13] Hammer, K., Hanelt, P., Knüppfer, H. (1982): Vorarbeiten zur monographischen Darstellung von Wildpflanzensortimenten: Agrostemma L. [Preliminary study for the monographic display of wild plants: Agrostemma L.] Kulturpflanze 30(1). p. 45-96.

[14] Holzner, W. (1982): Concepts, categories and characteristics of weeds. IN: Holzner, W., Numata, M. (szerk.): Biology and Ecology of Weeds. Geobotany 2. Dr. W. Junk Publishers. The Hague. p. 3-20.

[15] Holzner, W. (1991): Unkraut-Typen. Eine Einteilung der Ruderal- und Segetalpflanzen nach komlexen biologischökologischen Kriterien. II. Teil: Die „ein- und zweijährigen” Arten. [Weed types. A division of ruderal and segetal plants according to complex biological-ecological criteria. Part II: The "one and two year" species]. Die Bodenkultur. 42. p. 1-20.

[16] Hunyadi K. (szerk.) (1988): Szántóföldi gyomnövények és biológiájuk. [Arable weeds and their biology]. Mezőgazdasági Kiadó. Budapest. p. 17-21.

[17] Jacomet, S., Kreuz, A. (1999): Archäobotanik. Aufgaben, Methoden und Ergebnisse vegetations- und agrargeschichtlicher Forschung. [Archeobotany. Tasks, methods and results of vegetation and agricultural history research]. Verlag Eugen Ulmer. Stuttgart. p. 368.

[18] Jelitto Staudensamen (2014): www.jelitto.com [16-04-2020]

[19] Kadereit, J. (1990): Some suggestions on the geographical origin of the central, west and north European synanthopic species of Papaver L. Botanical Journal of the Linnean Society. 103 (3). p. 221-231.

[20] Kapás S. (szerk.) (1969): Magyar növénynemesítés. [Hungarian plant breeding]. Akadémiai Kiadó. Budapest. p. 53.

[21] Körber-Grohne, U. (1995): Nutzpflanzen in Deutschland von der Vorgeschichte bis heute. [Useful plants in Germany from prehistory to the present day]. Konrad Theiss Verlag. Stuttgart. p. 389-396.

[22] Kornaś, J. (1988): Speirochore Ackerwildkräuter: von ökologischer Spezialisierung zum Aussterben. [Speirochore arable weeds: from ecological specialization to extinction]. Flora 180. p. 83-91.

[23] McCulley, D., McCulley, L. (2014): www.swallowtailgardenseeds.com [16-04-2020]

[24] Pickersgill, B. (1981): Biosystematics of crop-weed complexes. Die Kulturpflanze. 29(1). p. 377-388. 
[25] Pinke Gy. (1999): Veszélyeztetett szegetális gyomnövények és fenntartásuk lehetőségei európai tapasztalatok alapján. [Endangered segetal weeds and possibilities for their maintenance based on European experience]. Kitaibelia. 4(1). p. 95-110.

[26] Pinke Gy., Pál R. (2005): Gyomnövényeink eredete, termőhelye és védelme. [Origin, terroir and protection of our weeds]. Alexandra Kiadó. Szeged. p. 22-26.

[27] Raven, S. (2008): www.sarahraven.com [16-04-2020]

[28] Rothmaler, W. (1946): Artenstehung in historischer Zeit, am Beispiel der Unkräuter des Kulturleins (Linum usitatissimum). [Species formation in historical time, using the example of the weeds of cultivated flax (Linum usitatissimum)]. Züchter 17-18(3). p. 89-92.

[29] Scholz, H. (1996): Ursprung und Evolution obligatorischer Unkräuter. [Origin and evolution of obligate weeds]. In: Fritsch R., Hammer, K.: Evolution und Taxonomie von pflanzengenetischen Resourcen. [Evolution and taxomony of plant genetic resources]. Bonn. p. 109-129.

[30] Schroeder. F. G. (1968): Zur klassifizierung der Anthropochoren. [Classification of anthropochors]. Plant Ecology. 16(5). p. 225-238.

[31] Sinskaia, E., Beztuzheva, A. (1930): The forms of Camelina sativa in connection with climate, flax and man. Bull. Appl. Bot. 25(2). p. 88-200.

[32] Szikura J. (2002): A növényhonosítás jelentősége a múltban, napjainkban és a jövőben. [The importance of plant naturalization in the past, today and in the future]. (MTA Székfoglaló). Akaprint Nyomdaipari Kft. Budapest. p. 57.

[33] Terpó A., Zając, M., Zając, A. (1999): Provisional list of Hungarian archaephytes. Thaiszia - Journal of botany. Slovakia. 9. p. 41-47.

[34] The Royal Horticultural Society (2014): www.rsh.org.uk [16-04-2020]

[35] Thellung, A. (1918-1919): Zur Terminologie der Adventiv- und Ruderalflora. [The terminology of the adventive and ruderalflora]. Allgemeine Botanische Zeitschrift. 24. p. 36-43.

[36] Thompson and Morgan (2004): www.thompson-morgan.com [16-04-2020]

[37] Udvardy L. (2000): Archaikus gabonagyomjaink, mint dísznövények. [Our archaic cereal weeds as ornamentals]. In: Gyulai F. (szerk.): Az agrobiodiverzitás megőrzése és hasznosítása, Szimpózium Jánossy Andor emlékére. [Preservation and utilization of agrobiodiversity, symposium in memory of Andor Jánossy]. Agrobotanikai Intézet. Tápiószele. p. 415-419. 